\title{
The T-box transcription factor Brachyury regulates epithelial-mesenchymal transition in association with cancer stem-like cells in adenoid cystic carcinoma cells
}

Miyuki Shimoda ${ }^{\dagger}$, Tsuyoshi Sugiura ${ }^{* \dagger}$, Ikumi Imajyo, Kotaro Ishii, Satomi Chigita, Katsuhiro Seki, Yousuke Kobayashi and Kanemitsu Shirasuna

\begin{abstract}
Background: The high frequencies of recurrence and distant metastasis of adenoid cystic carcinoma (AdCC) emphasize the need to better understand the biological factors associated with these outcomes. To analyze the mechanisms of AdCC metastasis, we established the green fluorescence protein (GFP)-transfected subline ACCS-GFP from the AdCC parental cell line and the metastatic ACCS-M GFP line from an in vivo metastasis model.

Methods: Using these cell lines, we investigated the involvement of the epithelial-mesenchymal transition (EMT) and cancer stem cell (CSCs) in AdCC metastasis by real-time RT-PCR for EMT related genes and stem cell markers. Characteristics of CSCs were also analyzed by sphere-forming ability and tumorigenicity. Short hairpin RNA (shRNA) silencing of target gene was also performed.

Results: ACCS-M GFP demonstrated characteristics of EMT and additionally displayed sphere-forming ability and high expression of EMT-related genes (Snail, Twist1, Twist2, Slug, zinc finger E-box binding homeobox 1 and 2 [Zeb1 and Zeb2], glycogen synthase kinase 3 beta [Gsk3 $\beta$ and transforming growth factor beta 2 [Tgf- $\beta 2]$ ), stem cell markers (Nodal, Lefty, Oct-4, Pax6, Rex1, and Nanog), and differentiation markers (sex determining region Y [Sox2], Brachyury, and alpha fetoprotein [Afp]). These observations suggest that ACCS-M GFP shows the characteristics of CSCs and CSCs may be involved in the EMT of AdCC. Surprisingly, shRNA silencing of the T-box transcription factor Brachyury (also a differentiation marker) resulted in downregulation of the EMT and stem cell markers. In addition, sphere-forming ability, EMT characteristics, and tumorigenicity were simultaneously lost. Brachyury expression in clinical samples of AdCC was extremely high and closely related to EMT. This finding suggests that regulation of EMT by Brachyury in clinical AdCC may parallel that observed in vitro in this study.

Conclusions: The use of a single cell line is a limitation of this study. However, parallel data from in vitro and clinical samples suggest the possibility that EMT is directly linked to CSCS and that Brachyury is a regulator of EMT and CSCs.
\end{abstract}

Keywords: Brachyury, Epithelial mesenchymal transition (EMT), Cancer stem cell (CSC), Adenoid cystic carcinoma $(\mathrm{AdCC})$

\footnotetext{
* Correspondence: sugiura@dent.kyushu-u.ac.jp

${ }^{\dagger}$ Equal contributors

Division of Maxillofacial Diagnostic and Surgical Sciences, Department of Oral and Maxillofacial Surgery, Graduate School of Dental Science, Kyushu University, 3-1-1 Maidashi, Higashi-ku, Fukuoka 812-8582, Japan
} 


\section{Background}

Adenoid cystic carcinoma (AdCC) is one of the most common malignant tumors of the salivary glands and is characterized by unique clinical features and behavior. AdCC grows slowly but spreads relentlessly into adjacent tissues. The frequencies of recurrence and distant metastasis of AdCC are very high, with $40-60 \%$ of AdCC patients developing distant metastases to the lungs, bone, and soft tissues [1,2]. Therefore, distant failure remains a significant obstacle to the long-term cure of patients with AdCC, emphasizing the need to better understand the biological factors associated with AdCC distant metastases.

To identify the factors that mediate AdCC metastasis, we established 3 AdCC cell lines expressing green fluorescent protein (GFP) from the ACCS cell line by using orthotopic transplantation and in vivo selection in the nude mouse: the parental ACCS-GFP, the highly tumorigenic ACCS-T GFP, and the metastatic ACCS-M GFP. These cells were subjected to DNA microarray analysis, and the results revealed significantly altered biological processes in ACC-M GFP, including events related to cell adhesion and signaling. In particular, a significant downregulation of cell adhesion molecules such as E-cadherin and integrin subunits was observed. We confirmed the loss of E-cadherin and integrins and gain of vimentin in ACCS-M GFP, suggesting that the epithelial-mesenchymal transition (EMT) is a putative event in AdCC metastasis and induces tumor cell dissemination from the primary tumor site [3].

Recent evidence has demonstrated that the EMT is involved in a dedifferentiation program in epithelial tumor progression. This process interrupts cell-to-cell contact in a homocellular fashion in tumors and allows the dissemination of a single cell from the primary site. Therefore, EMT may be one of the important phenotypic alterations promoting nonmetastatic tumor transition to metastatic carcinoma $[4,5]$.

The EMT program triggered during tumor progression appears to be controlled by genes normally expressed in the early embryo, including Twist, Snail, Slug, Goosecoid, and Sip1 [6-11]. The transcription factors encoded by these genes can impart the traits of mesenchymal cells to tumor cells, including motility and invasiveness. The expression of Twist, for example, is elevated in various types of cancers including breast, prostate, gastric, and melanoma [12]. In addition, the T-box transcription factor Brachyury, a gene required for mesoderm formation during the development process [13-15], is also reportedly able to promote the EMT in human carcinoma cell lines [16]. The latter study additionally revealed that overexpression of Brachyury (also described as a mesoderm differentiation marker) in human carcinoma cells induced changes characteristic of
EMT. Therefore, mechanisms similar to EMT in human developmental processes are proposed to control EMT in cancer cells.

Independent of these studies, neoplastic tissue studies have provided evidence of self-renewing, stem-like cells within tumors, termed cancer stem cells (CSCs). CSCs constitute a minority of neoplastic cells within a tumor and are defined operationally by their ability to seed new tumors. For this reason, they have also been called "tumor-initiating cells" [17]. During the process of tumor metastasis, which is often enabled by EMT [18], disseminated cancer cells presumably require a self-renewal capability similar to that exhibited by stem cells in order to spawn macroscopic metastases. This phenomenon raises the possibility that the EMT process, which enables cancer cell dissemination, may also impart a self-renewal capability to disseminating cancer cells. Indeed, emerging evidence of a direct interaction between EMT and CSCs has been recently reported [16,19-22]. CSCs were shown to be resistant to chemotherapy and radiotherapy [21,23] and these studies therefore provide a new concept for therapies that target CSCs [24-28].

Given these reports and our previous results, we hypothesized that the EMT in our AdCC metastasis model involves AdCC stem cells and that the development of anti-CSC therapy may be effective in the treatment of AdCC. In this study, we demonstrate evidence of a direct interaction between the EMT and CSCs in the highly metastatic AdCC subclone ACCS-M GFP. We also report that the T-box transcription factor Brachyury [29-31] is a possible central regulator of CSCs and the EMT in AdCC cells.

\section{Results}

\section{AdCC cells with EMT characteristics also have CSC-like phenotypes}

We previously isolated the highly metastatic and tumorigenic AdCC subline ACCS-M GFP from nonmetastatic ( $0 \%$ incidence) and low tumorigenic ( $22.2 \%$ incidence) parental ACCS GFP cells using in vivo selection as described in the Methods [3]. ACCS-M GFP exhibited high tumorigenicity (100\% incidence), high frequency of spontaneous metastasis to submandibular lymph nodes (100\% incidence), and significant characteristic changes of the EMT, such as loss of E-cadherin and gain of vimentin [3]. Ample evidence has accumulated indicating that the EMT is closely correlated with CSCs. AdCC cells with the EMT phenotype (ACCS-M GFP) also showed significant tumorigenicity, which is an important phenotype of CSCs [3]. Therefore, we assessed the stemness of ACCS cell lines with the sphere-forming assay. The parental ACCS GFP cells demonstrated weak sphere-forming capacity in diameter and number, whereas ACCS-M GFP cells showed significant sphere- 
forming capacity (Figure1). The sphere diameter of ACCS-M GFP was approximately twice the diameter of ACCS GFP in the primary and secondary spheres (Figure 1B). Furthermore, the number of spheres was more significantly different in the secondary spheres than in the primary spheres. The number of spheres of ACCS-M GFP was approximately 10 times higher than that of ACCS GFP (Figure 1C). These data suggest that ACCS-M GFP cells have self-renewal (sphere-forming) ability.

\section{AdCC cells with EMT characteristics express EMT-related genes and stem-cell markers}

We next quantified the expression levels of possible CSC markers by real-time RT-PCR, which are shown as relative mRNA levels compared to $\beta$-actin mRNA (Table 1). ACCS cells expressed higher levels of genes such as Snail, Slug, Tgf- $\beta 2$, Pax6, and Brachyury than other genes tested. Expression levels of EMT-related genes such as Snail, Twist1, Twist2, Slug, zinc finger E-box binding homeobox 1 and 2 (Zeb1 and Zeb2), glycogen synthase kinase 3 beta (Gsk3 $\beta$ and transforming growth factor beta 2 (Tgf- $\beta 2$ ) were elevated from 2 -fold to 9-fold in ACCS-M GFP compared to ACCS
GFP (Figure 2A). This increased expression in ACCS-M GFP was especially apparent with Slug (approximately 4-fold), Zeb1 (approximately 9-fold), and Zeb2 (approximately 5.5-fold). Stem cell markers (Nodal, Lefty, Oct-4, Pax6, Rex1, and Nanog) and differentiation markers (sex determining region Y [Sox2], Brachyury, and Afp) were also overexpressed in ACCS-M GFP, with the exception Oct-4 and Nanog (Figure 2B). Together, these data suggest that ACCS-M GFP cells have CSC-like phenotypes and are related to the EMT.

\section{Knockdown of the T-box transcription factor Brachyury downregulates EMT-related genes and stem-cell markers} We next sought direct evidence of linkage between EMT and CSCs with the aim to simultaneously reveal the central regulator(s) of CSC stemness. Several of the CSC markers in Figure 2 are transcription factors, and recent reports have demonstrated that the T-box transcription factor Brachyury promotes the EMT in human tumor cells $[16,32]$. Therefore, we focused on the possibility that Brachyury regulates not only EMT but also CSC stemness. We also focused on SOX2, which has also been reported as one of the key element genes for embryonic or pluripotent stem cells. We used a stable

A

$2^{\text {nd }}$ sphere

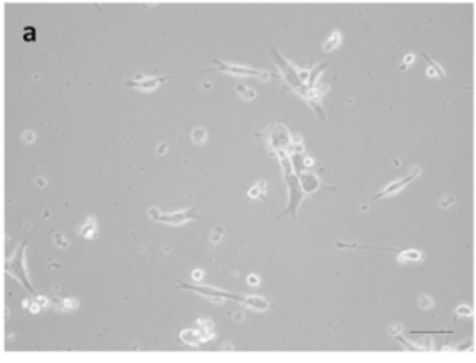

ACCS GFP

B

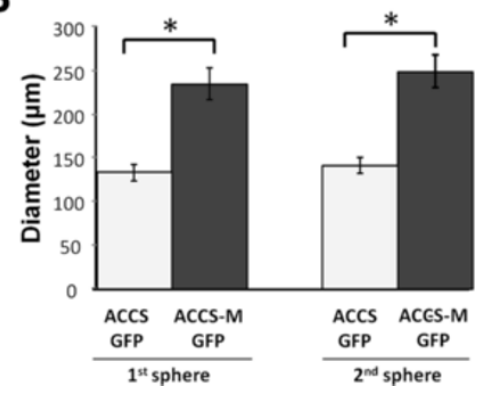

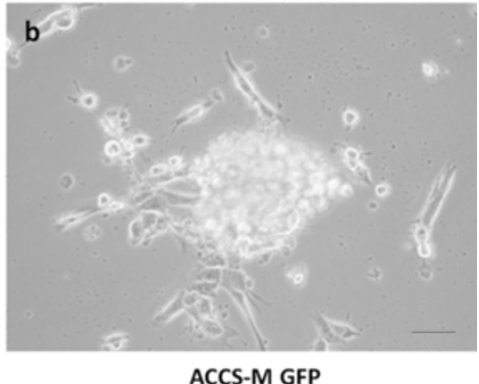

C

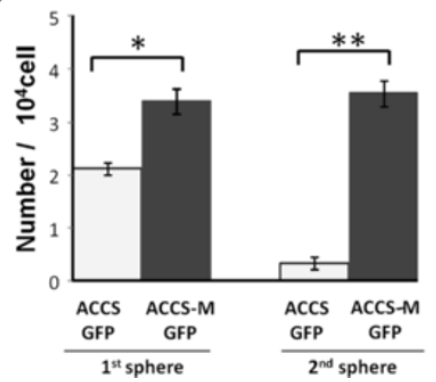

Figure 1 Cells with EMT alterations show sphere-forming ability. ACCS-GFP and ACCS-M GFP cells were cultured at a density of $5 \times 10^{4}$ cells/ $\mathrm{mL}$ in serum-free medium containing $40 \mathrm{ng} / \mathrm{mL}$ bFGF and $20 \mathrm{ng} / \mathrm{mL}$ EGF for floating culture for 10 days (primary spheres). For secondary spheres, primary spheres (day 10) were dissociated into single cells and further cultured at a density of $1 \times 10^{4}$ cells $/ \mathrm{mL}$ for 10 days. Spheres were observed under a phase contrast microscope (A). Sphere diameters were measured (B), and spheres with a diameter $>100 \mu \mathrm{m}$ were counted. Sphere numbers were standardized as sphere number $/ 10^{4}$ cells originally cultured $(\mathbf{C})$ in each sphere period. Experiments were performed in triplicate, and the values were averaged. Bars indicate the standard deviation. Data significance was analyzed by Student's $t$-test. ${ }^{*} P<0.05$, **P $<0.01$. 
Table 1 Analysis of gene expression levels related to EMT and CSCs by real-time PCR

\begin{tabular}{|c|c|c|c|}
\hline \multirow[t]{2}{*}{ Genes } & \multirow{2}{*}{$\begin{array}{l}\text { Cell } \\
\text { line }\end{array}$} & \multicolumn{2}{|c|}{ Relative mRNA level (normalized to $\beta$-actin) } \\
\hline & & Mean expression levels & SD \\
\hline \multirow[t]{2}{*}{ Snail } & ACCS & $2.02 \times 10^{-2}$ & $4.18 \times 10^{-3}$ \\
\hline & ACCSM & $5.14 \times 10^{-2}$ & $2.62 \times 10^{-3}$ \\
\hline \multirow[t]{2}{*}{ Slug } & ACCS & $1.05 \times 10^{-2}$ & $4.82 \times 10^{-3}$ \\
\hline & ACCSM & $4.14 \times 10^{-2}$ & $2.92 \times 10^{-3}$ \\
\hline \multirow[t]{2}{*}{ Twist1 } & ACCS & $1.47 \times 10^{-4}$ & $5.24 \times 10^{-5}$ \\
\hline & ACCSM & $3.37 \times 10^{-4}$ & $1.12 \times 10^{-5}$ \\
\hline \multirow[t]{2}{*}{ Twist2 } & ACCS & $4.68 \times 10^{-3}$ & $2.67 \times 10^{-4}$ \\
\hline & ACCSM & $8.04 \times 10^{-3}$ & $1.38 \times 10^{-4}$ \\
\hline \multirow[t]{2}{*}{ Zeb1 } & ACCS & $3.21 \times 10^{-3}$ & $5.13 \times 10^{-4}$ \\
\hline & ACCSM & $2.92 \times 10^{-2}$ & $6.16 \times 10^{-4}$ \\
\hline \multirow[t]{2}{*}{ Zeb2 } & ACCS & $1.40 \times 10^{-3}$ & $6.23 \times 10^{-4}$ \\
\hline & ACCSM & $7.39 \times 10^{-3}$ & $4.12 \times 10^{-4}$ \\
\hline \multirow[t]{2}{*}{ Tgf- $\beta 2$} & ACCS & $5.43 \times 10^{-2}$ & $3.56 \times 10^{-2}$ \\
\hline & ACCSM & $1.81 \times 10^{-1}$ & $7.52 \times 10^{-2}$ \\
\hline \multirow[t]{2}{*}{ Gsk3 $\beta$} & ACCS & $3.39 \times 10^{-3}$ & $1.82 \times 10^{-4}$ \\
\hline & ACCSM & $8.73 \times 10^{-3}$ & $6.43 \times 10^{-4}$ \\
\hline \multirow[t]{2}{*}{ Nodal } & ACCS & $3.72 \times 10^{-3}$ & $4.36 \times 10^{-4}$ \\
\hline & ACCSM & $7.14 \times 10^{-3}$ & $2.15 \times 10^{-4}$ \\
\hline \multirow[t]{2}{*}{ Pax 6} & ACCS & $6.34 \times 10^{-2}$ & $4.26 \times 10^{-2}$ \\
\hline & ACCSM & $1.10 \times 10^{-1}$ & $8.21 \times 10^{-2}$ \\
\hline \multirow[t]{2}{*}{ Rex 1} & ACCS & $1.12 \times 10^{-3}$ & $2.42 \times 10^{-4}$ \\
\hline & ACCSM & $2.45 \times 10^{-3}$ & $2.93 \times 10^{-4}$ \\
\hline \multirow[t]{2}{*}{ Lefty } & ACCS & $3.39 \times 10^{-3}$ & $1.51 \times 10^{-4}$ \\
\hline & ACCSM & $9.88 \times 10^{-3}$ & $7.12 \times 10^{-4}$ \\
\hline \multirow[t]{2}{*}{ Brachyury } & ACCS & $1.55 \times 10^{-2}$ & $5.32 \times 10^{-3}$ \\
\hline & ACCSM & $2.83 \times 10^{-2}$ & $6.24 \times 10^{-3}$ \\
\hline \multirow[t]{2}{*}{ Sox 2} & ACCS & $9.35 \times 10^{-3}$ & $2.12 \times 10^{-4}$ \\
\hline & ACCSM & $1.94 \times 10^{-2}$ & $8.92 \times 10^{-4}$ \\
\hline \multirow[t]{2}{*}{ AFP } & ACCS & $9.50 \times 10^{-3}$ & $3.52 \times 10^{-4}$ \\
\hline & ACCSM & $1.83 \times 10^{-2}$ & $9.96 \times 10^{-4}$ \\
\hline
\end{tabular}

transfection system for Brachyury and SOX2 short hairpin RNA (shRNA) in lentiviral plasmids. Following Brachyury and SOX2 knockdown, the expression levels of all examined CSC markers were assessed by real-time RT-PCR (Figure 3). Each mRNA level was compared with ACCS GFP, and data are shown as relative mRNA levels (ACCS GFP =1). The expression levels of EMTrelated genes (Figure 3A) and stem cell markers and differentiation markers (Figure $3 \mathrm{~B}$ ) are shown. The mRNA levels of all CSC markers decreased in Brachyuryknockdown ACCS-M GFP cells (ACCS-M shBra) compared to ACCS GFP. In contrast, SOX2-knockdown ACCS-M GFP cells (ACCS-M shSOX2) demonstrated specific downregulation of only Snail, Zeb1, Zeb2, Tgfß2, Rex1, Nanog, and Afp mRNA. Importantly, SOX2 knockdown failed to regulate Brachyury mRNA expression. These results strongly suggest that Brachyury is a central regulator of CSC and EMT.

\section{Knockdown of the T-box transcription factor Brachyury negates EMT phenotypes}

We then confirmed the EMT phenotype in ACCS-M shBra and ACCS-M shSOX2. The protein level of $\beta$-catenin was increased and shifted to higher molecular weight in ACCS-M GFP. The protein level of $\beta$-catenin was decreased in ACCS-M shBra and ACCS-M shSOX2 cells, reaching similar levels to that observed in ACCS GFP; however, the molecular weight of $\beta$-catenin was increased, similar to ACCS-M GFP.

The protein level of E-cadherin was increased in ACCS-M shBra and recovered to the approximate level observed in ACCS GFP cells, but recovery in ACCS-M shSOX2 was incomplete (Figure 4). Vimentin protein level was decreased in both ACCS-M shBra and ACCS-M shSOX2 cells compared to ACCS-M GFP, reaching similar levels to that observed in ACCS GFP.

\section{Knockdown of the T-box transcription factor Brachyury inhibits sphere-forming capacity}

We examined the self-renewal capability of ACCS-M shBra and ACCS-M shSOX2 by sphere-forming assay. Similar to ACCS GFP cells, ACCS-M shBra and ACCS-M shSOX2 lost sphere-forming capacity with respect to the diameter of the primary (Figure 5A) and secondary spheres (Figure 5B) and with respect to the number of cells in the primary spheres (Figure $5 \mathrm{C}$ ). Furthermore, the number of spheres was more significantly lower in the secondary spheres than in the primary spheres, and ACCS-M shBra significantly reduced sphere number in comparison to ACCS-M shSOX2 (Figure 5D). These data suggest that Brachyury is a more important regulator of EMT and CSC than SOX2.

\section{Knockdown of the T-box transcription factor Brachyury inhibits tumorigenicity and metastasis in vivo}

The effect of Brachyury knockdown on ACCS-M GFP tumorigenicity and metastasis in vivo was examined using a mouse metastasis model established and reported by Ishii et al. [3]. Figure 6A shows a typical tumor in tongue $(\mathrm{a}-\mathrm{c})$, its GFP excitation $(\mathrm{d}-\mathrm{f})$, and submandibular lymph node metastasis (g-i). Remarkably, ACCS-M shBra sometimes failed to develop into tongue tumor (50\% tumorigenicity), and metastasis was completely inhibited. ACCS-M shSOX2 also reduced tumorigenicity $(87.5 \%)$ and metastasis $(87.5 \%)$, but the impact of inhibition was more relevant with ACCS-M 

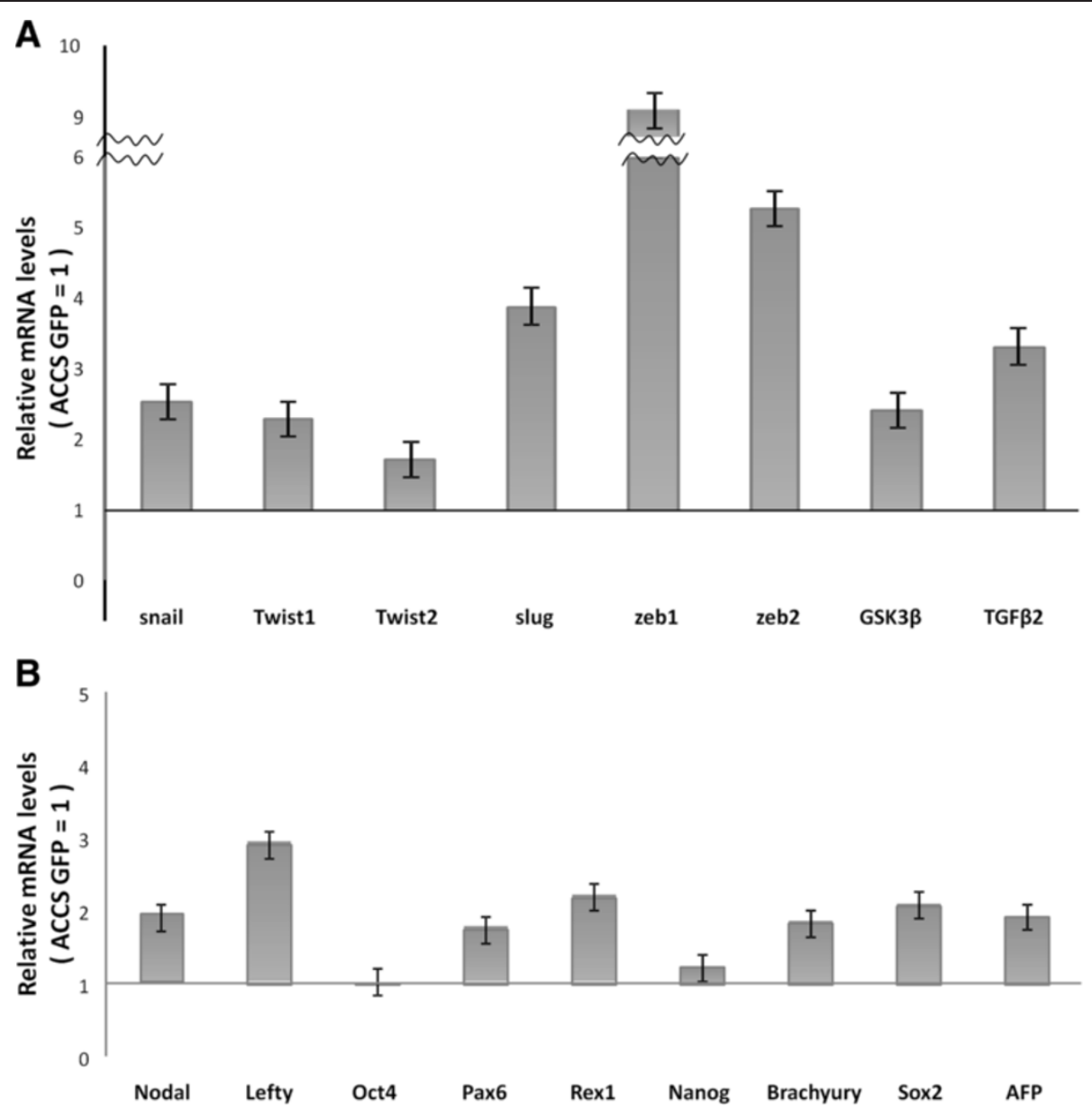

Figure 2 Analysis of gene expression related to EMT and CSCs by real-time PCR. The mRNA expression levels of the indicated EMT-related genes (A) and embryonic stem cell markers (Nodal, Pax6, Rex1, Lefty, Oct-4, and Nanog) and differentiation markers (mesoderm marker: Brachyury; ectoderm marker: Sox2; endoderm marker: AFP) (B) in ACC cells were quantified by real-time RT-PCR. Each mRNA level was compared between ACCS GFP and ACCS-M GFP, and data are shown as relative mRNA levels to $\beta$-actin mRNA. Experiments were performed in triplicate, and the number of adhered cells was averaged. Bars indicate the standard deviation.

shBra (Table 2). Tumor growth rate was also significantly inhibited in ACCS-M shBra cells (Figure 6B).

\section{Expression and molecular localization of Brachyury and EMT markers in oral AdCC lesions}

We examined the expression and expression pattern of Brachyury in oral AdCC lesions using immunohistochemistry. Figure 7A shows the representative staining pattern of Brachyury on AdCC (a: tubular pattern. b: cribriform pattern, c: solid pattern). Brachyury was localized to the cytoplasm and/or nucleus of AdCC cells. We examined 21 AdCC samples, and all samples demonstrated positive expression of Brachyury in AdCC cells (positive expression rate $=100 \%$, Table 3 ). To find evidence that Brachyury was associated with EMT, we analyzed localization of Brachyury (Figure. 7B-b), E-cadherin (Figure. 7B-c), and vimentin (Figure. 7B-d) in AdCC tissue by immunofluorescence staining of serial sections. The lateral layer of the AdCC cells expressed Brachyury in the nucleus (Figure. 7B-b, arrowheads). These cells lost expression of E-cadherin (Figure. 7B-c, arrowheads) and gained expression of vimentin (Figure. 7B-d, arrowheads).

\section{Discussion}

Cancer metastasis is the most crucial event directly influencing patient prognosis. Recent studies suggest that the EMT is strongly correlated with cancer invasion and metastasis [33,34]. In contrast, CSCs have gained attention as targets for cancer treatment because they show chemo- and radioresistance [21,35-37]. More recently, EMT was reported to promote the CSC signature [19,38-40]; however, the regulatory mechanism of CSC and EMT is still unclear.

We demonstrated a direct correlation between EMT and CSCs in AdCC cells. Importantly, the EMT we 


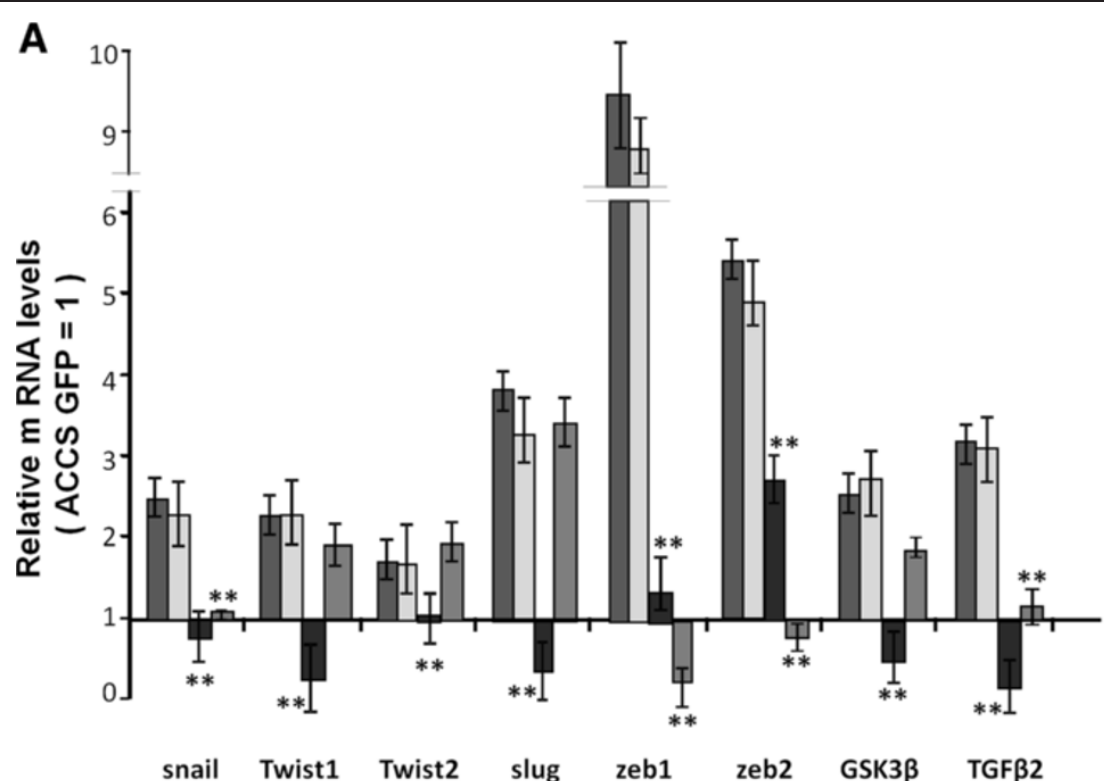

B

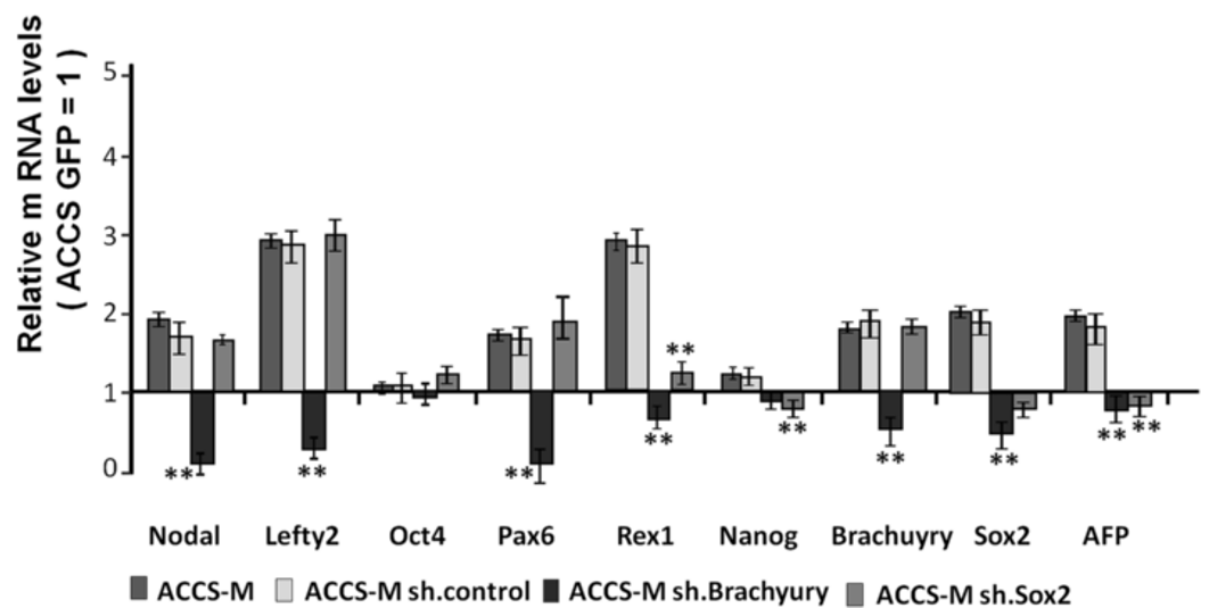

Figure 3 Effect of Brachyury shRNA on ACCS-M GFP gene expression related to EMT and CSCs. ACCS-M-sh. control was generated by the transfection of ACCS-M GFP cells with control vector. ACCS-M sh Brachyury and ACCS-M sh Sox2 were generated by the transfection of ACCS-M GFP cells with Brachyury shRNA and Sox2 shRNA, respectively. The mRNA expression levels of the indicated genes in ACCS-M GFP cells and derivatives were quantified by real-time RT-PCR. Each mRNA level was compared with ACCS GFP, and data are shown as relative mRNA levels (ACCS GFP $=1$ ). The expression levels of EMT-related genes $(\mathbf{A})$ and stem cell markers and differentiation markers $(\mathbf{B})$ are shown. Experiments were performed in triplicate, and the number of adhered cells was averaged. Bars indicate the standard deviation.

analyzed in this study was developed from an in vivo model and was not artificially isolated [33], exogenous [41,42], or genetically promoted [43], as described previously. Therefore, the findings that we report here strongly support the hypothesis that CSCs are involved in the EMT. This study is the first to identify Brachyury as a regulator for both EMT and CSC characteristics. This conclusion is based on the observation that Brachyury knockdown resulted in simultaneous loss of all stem cell markers and loss of EMT and CSC phenotypes in morphological and biochemical assays.
The classification of EMT into 3 subtypes based on the biological and biomarker context in which they occur has been proposed [44,45]. EMT associated with organ development is referred to as type 1 EMT, and EMT associated with wound healing and tissue regeneration are type 2 EMT. EMT in cancer progression and metastasis is categorized as type 3 EMT. Multiple extracellular signals including TGF- $\beta$, receptor tyrosine kinases, Notch, nuclear factor kappa B (NFKB), and Wnt can initiate the type 3 EMT program. The downstream intracellular signaling pathways and transcription factors 


\begin{tabular}{|c|c|c|c|c|c|c|c|c|c|c|}
\hline & \multirow[t]{2}{*}{$\begin{array}{c}\text { ACCS } \\
\text { GFP }\end{array}$} & \multirow[t]{2}{*}{$\begin{array}{c}\text { ACCS-M } \\
\text { GFP }\end{array}$} & \multicolumn{2}{|c|}{$\begin{array}{c}\text { ACCS } \\
\text { GFP }\end{array}$} & \multicolumn{2}{|c|}{$\begin{array}{c}\text { ACCS-M } \\
\text { GFP }\end{array}$} & \multicolumn{2}{|c|}{$\begin{array}{l}\text { ACCS } \\
\text { GFP }\end{array}$} & \multicolumn{2}{|c|}{$\begin{array}{c}\text { ACCS-M } \\
\text { GFP }\end{array}$} \\
\hline & & & $\begin{array}{l}\text { Sh. } \\
\text { Con }\end{array}$ & $\begin{array}{l}\text { Sh. } \\
\text { Bra }\end{array}$ & $\begin{array}{l}\text { Sh. } \\
\text { Con }\end{array}$ & $\begin{array}{l}\text { Sh. } \\
\text { Bra }\end{array}$ & $\begin{array}{l}\text { Sh. } \\
\text { Con }\end{array}$ & $\begin{array}{l}\text { Sh. } \\
\text { Sox2 }\end{array}$ & $\begin{array}{l}\text { Sh. } \\
\text { Con }\end{array}$ & $\begin{array}{l}\text { Sh. } \\
\text { Sox2 }\end{array}$ \\
\hline$\beta$-catenin & $=$ & $=$ & Ei & 21 & 89 & $2=$ & Lill & 8 & $=$ & 20 \\
\hline E-cadherin & 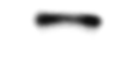 & -- & - & - & - & $\longrightarrow$ & $=$ & $\infty$ & $\cdots$ & $m$ \\
\hline Vimentin & - & - & - & $\longrightarrow$ & 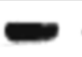 & 一。 & $m$ & - & $\infty$ & $m$ \\
\hline$\beta$-actin & - & $\longrightarrow$ & 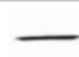 & 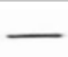 & - & - & 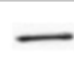 & - & $\longrightarrow$ & - \\
\hline
\end{tabular}

Figure 4 Silencing of Brachyury recovers the epithelial signature of ACCS-M GFP cells. sh control (sh. con) cells were generated by the transfection of ACCS GFP or ACCS-M GFP cells with control vector. sh Brachyury (sh.Bra) or sh SOX2 (sh.SOX2) cells were generated by the transfection of ACCS GFP or ACCS-M GFP cells with Brachyury shRNA or SOX2 shRNA. Cells were cultured for $24 \mathrm{~h}$ on culture dishes, and cell lysates were prepared and resolved using 10\% SDS-PAGE. The levels of EMT-related biomarkers were detected by immunoblotting with antibodies against the indicated proteins. All experiments were performed at least in triplicate, and representative results are shown.

that constitute this complex program demonstrate significant crosstalk, including multiple positive feedback loops $[46,47]$.

This principle of EMT suggests that the phenomenon may be reversible if such extracellular signals are removed. However, our established cell line, ACCS-M GFP, is stable and does not change to a nonmetastatic phenotype after several passages. Recent data from mammary epithelial cells also demonstrate that continuous activation of the EMT leads to epigenetic alterations in cells that induce heritable effects to maintain the EMT state even after EMT-inducing signals or factors are no longer present [48]. Hence, under certain conditions such as in vivo selection, EMT can yield stable changes in phenotype and thus the lineage identity of cells. In these cells, all possible pathways initiating EMT are constitutively active without any stimulation, as shown in Figure 3. This characteristic may make the cells self-renewing, the most important phenotype of CSCs. This type of phenotypic alteration or cell selection

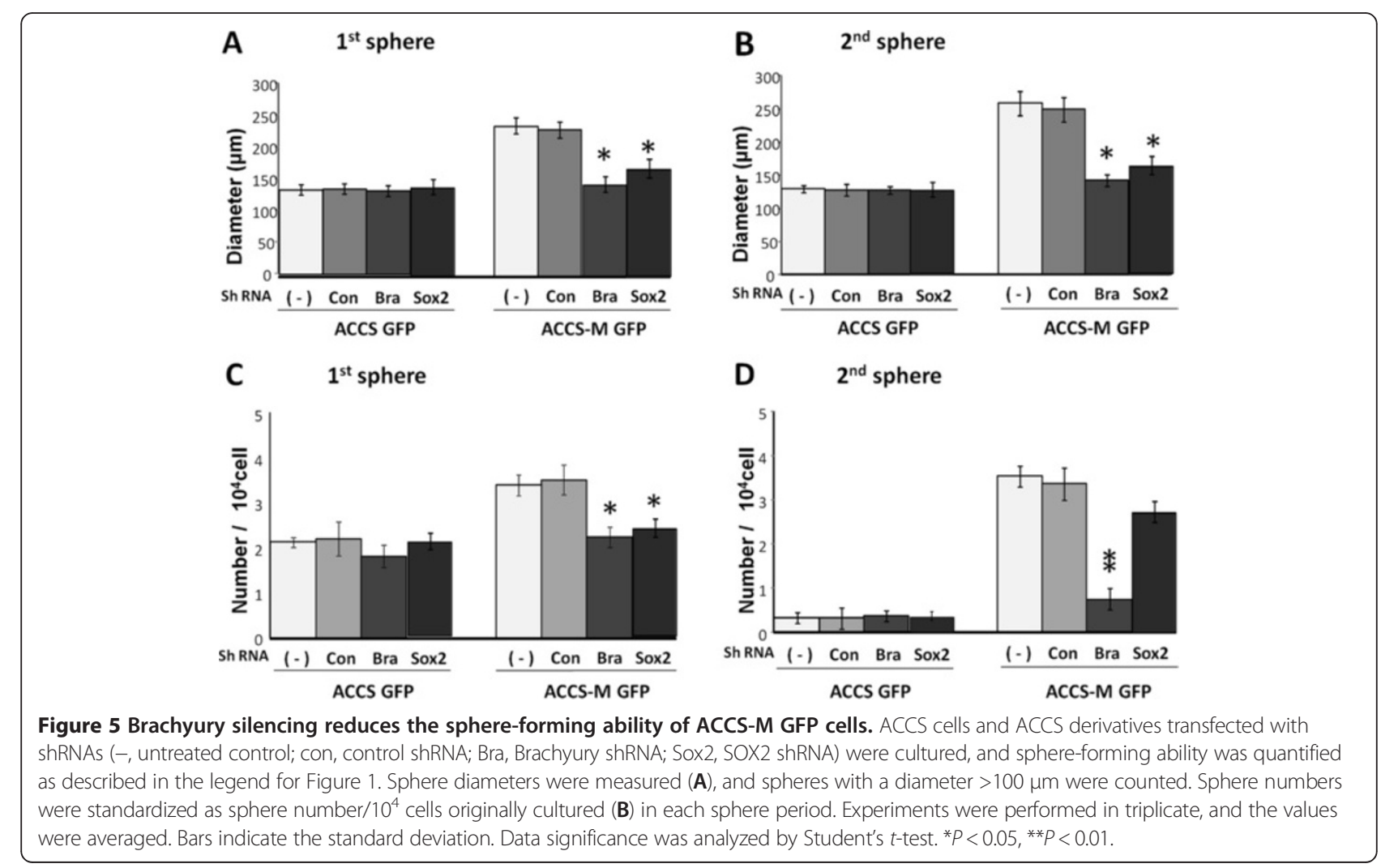




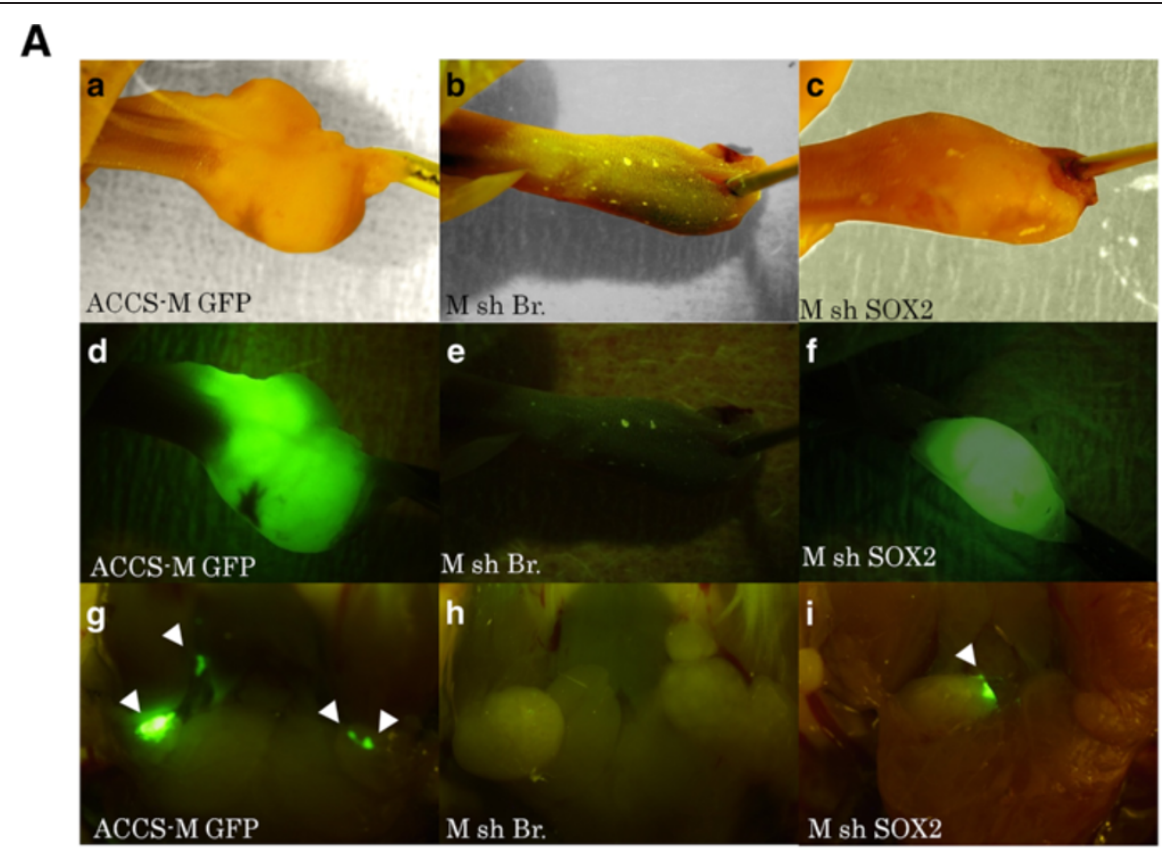

B

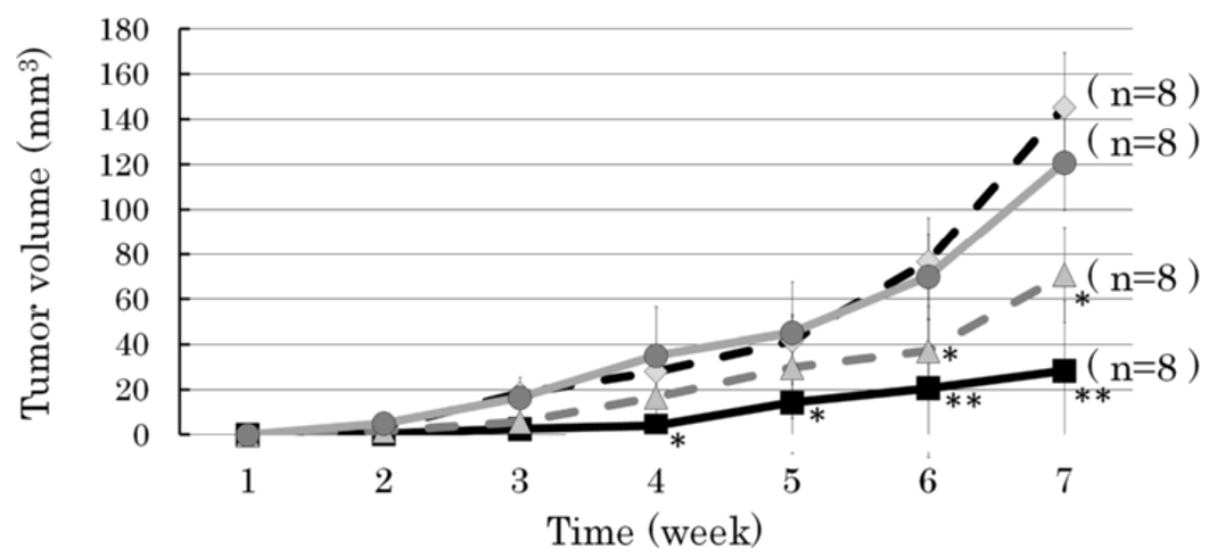

$\triangle \mathrm{ACCS}-\mathrm{M}$ GFP

M sh Br.

M sh SOX2

OM sh cont.

Figure 6 Brachyury silencing reduces the tumorigenicity and metastasis of ACCS-M GFP cells. A. ACCS-M GFP derivatives transfected with shRNAs (untreated control, ACCS-M GFP [a, d, g]; Brachyury shRNA, M sh.Bra [b, e, h]; SOX2 shRNA, M sh.SOX2 [c $\mathbf{c}, \mathbf{f}$ i $]$ ) were injected into the tongues of nude mice and examined to detect tumors in tongues (a-f) and spontaneous metastases in submandibular lymph nodes ( $\mathbf{g}-\mathbf{i})$. Observations with the naked eye $(\mathbf{a}-\mathbf{c})$ and the excitation of GFP $(\mathbf{d}-\mathbf{i})$ are shown. Sites of lymph node metastasis are labeled with arrowheads. Note that GFP enables the detection of micro-metastasis in the lymph nodes. B. The primary tumor volumes were measured weekly, calculated as the length $\times$ width $\times$ thickness, and mice were sacrificed when the primary tumor volume reached $100 \mathrm{~mm}^{3}$. Tumor growth curves for ACCS derivatives ACCS-M GFP (diamond), sh.Bra (square), sh.SOX2 (triangle), and sh cont. (control shRNA, circle) are shown. Experiments were performed in 6 mice for each ACCS derivative, and the values were averaged. Bars indicate the standard deviation. Data significances between ACCS-M GFP and other ACCS derivatives were analyzed by Student's t-test. ${ }^{*} P<0.05$, ${ }^{* *} P<0.01$.

is proposed to occur upon repeated chemotherapy or radiotherapy for cancer treatment in vivo.

Although much is known about the mechanisms or signals involved in type 1 and type 2 EMT [49,50], type 3 EMT-specific signaling still remains to be resolved in epithelial carcinoma cells. Our study indicates that one such possibility is the constitutive upregulation of TGF- $\beta 2$ in ACCS-M GFP cells. TGF- $\beta$ appears to be responsible for the induction or functional activation of a series of EMT-inducing transcription factors in cancer cells, notably Snail, Slug, ZEB1, Twist, Goosecoid, and FOXC2 [51-53]. Constitutive upregulation of TGF- $\beta 2$ would therefore maintain the EMT or CSC status in an autocrine manner. 
Table 2 Tumorigenicity and metastasis of each cell line

\begin{tabular}{lcccc}
\hline & \multicolumn{2}{c}{ Tumorigenicity } & \multicolumn{2}{c}{ Metastasis } \\
\cline { 2 - 5 } \multicolumn{1}{c}{ Cell line } & Tumorigenic mouse (\%) & Tumor volume $\left(\mathbf{m m}^{\mathbf{3}}\right)$ & ${ }^{\text {*SMLN (\%) }}$ & LUNG (\%) \\
\hline ACCS-M GFP & $8 / 8(100)$ & 145.3 & $8 / 8(100)$ & $7 / 8(87.5)$ \\
ACCS-M sh cont. & $8 / 8(100)$ & 121.4 & $8 / 8(100)$ & N.D \\
ACCS-M sh Br. & $4 / 8(50)$ & 28.3 & $7 / 8(87.5 \%)$ \\
ACCS-M sh SOX2 & $7 / 8(87.5)$ & 37.2 & $7 / 8(87.5)$ & N.D \\
\hline
\end{tabular}

N.D: not detected

*Submandibular lymph nodes.
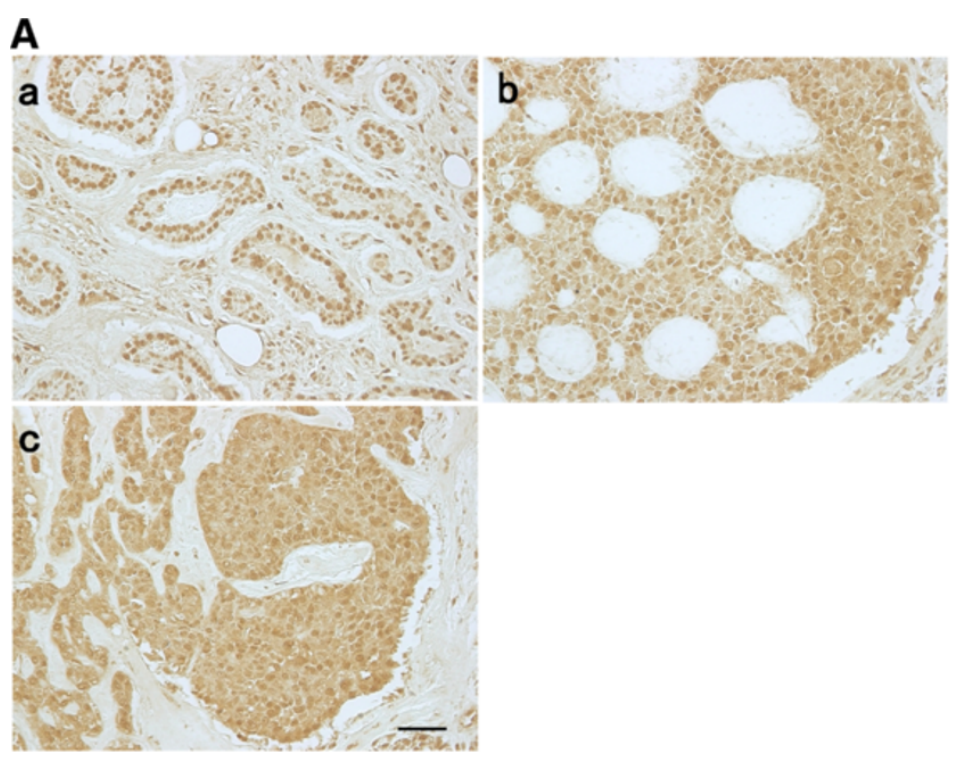

B

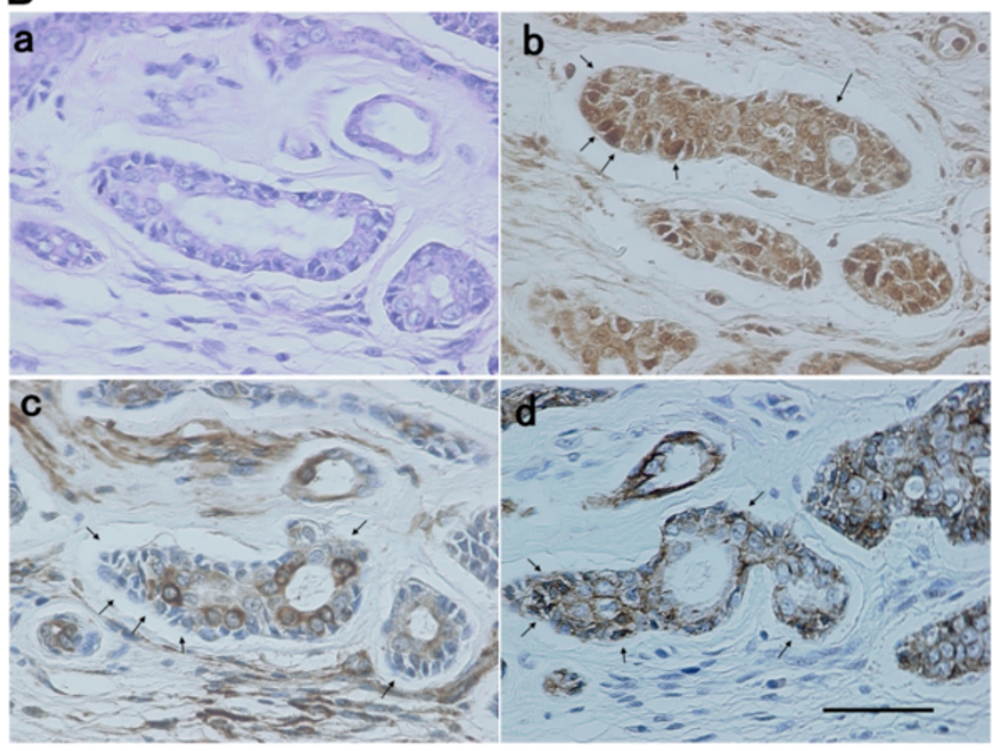

Figure 7 Immunohistochemical analysis of Brachyury, E-cadherin, and vimentin in AdCC tissue. Sections of 4- $\mu$ m thickness were used for the histopathological and immunohistochemical analysis as described in the Methods. A. Representative staining pattern of Brachyury on AdCC (a: tubular pattern, b: cribriform pattern, c: solid pattern). Bar $=50 \mu \mathrm{m}$. B. Serial AdCC sections were stained with HE (a) or immunostained with Brachyury (b), E-cadherin (c), and vimentin (d). Bar $=50 \mu \mathrm{m}$. 
Table 3 The clinical features and Brachyury expression patterns of patients with oral AdCC

\begin{tabular}{|c|c|c|c|c|c|c|c|c|}
\hline \multirow[t]{2}{*}{ Pt. } & \multirow[t]{2}{*}{ Sex } & \multirow{2}{*}{$\begin{array}{l}\text { Age } \\
\text { (y) }\end{array}$} & \multirow[t]{2}{*}{ Region } & \multirow{2}{*}{$\begin{array}{l}\text { Pathological } \\
\text { classification }\end{array}$} & \multirow{2}{*}{$\begin{array}{l}\text { Lymph } \\
\text { node } \\
\text { involvement }\end{array}$} & \multirow{2}{*}{$\begin{array}{l}\text { Distant } \\
\text { metastasis }\end{array}$} & \multicolumn{2}{|c|}{ Brachyury expression } \\
\hline & & & & & & & Nucleus & Cytoplasm \\
\hline 1 & M & 56 & Sublingual gland & Cribriform & - & - & + & + \\
\hline 2 & $\mathrm{~F}$ & 83 & Sublingual gland & Cribriform & - & - & + & + \\
\hline 3 & $\mathrm{~F}$ & 71 & Sublingual gland & Solid & - & Lung & + & + \\
\hline 4 & M & 70 & Sublingual gland & Cribriform & - & - & + & + \\
\hline 5 & M & 34 & Palate & Tubular & - & - & + & + \\
\hline 6 & $\mathrm{~F}$ & 25 & Palate & Cribriform & - & - & + & + \\
\hline 7 & $\mathrm{~F}$ & 64 & Upper gingiva & Tubular & - & Lung bone & + & + \\
\hline 8 & $\mathrm{~F}$ & 58 & Palate & Solid & + & - & + & + \\
\hline 9 & $\mathrm{~F}$ & 76 & Sublingual gland & Solid & + & - & + & + \\
\hline 10 & $\mathrm{~F}$ & 75 & Sublingual gland & Cribriform & + & - & + & - \\
\hline 11 & M & 58 & Palate & Cribriform & + & - & + & + \\
\hline 12 & $\mathrm{~F}$ & 80 & Sublingual gland & Cribriform & - & - & + & + \\
\hline 13 & M & 61 & Lower gingiva & Solid & - & Lung brain & + & + \\
\hline 14 & $\mathrm{~F}$ & 57 & Upper gingiva & Cribriform & - & Lung bone & + & + \\
\hline 15 & M & 63 & Palate & Solid & + & Liver & + & + \\
\hline 16 & $\mathrm{~F}$ & 59 & Palate & Tubular & - & - & + & + \\
\hline 17 & $\mathrm{~F}$ & 65 & Sublingual gland & Cribriform & - & - & + & + \\
\hline 18 & M & 65 & Upper gingiva & Solid & - & - & + & + \\
\hline 19 & $\mathrm{~F}$ & 70 & Sublingual gland & Solid & + & Lung & + & + \\
\hline 20 & M & 69 & Palate & Cribriform & - & - & + & + \\
\hline 21 & $\mathrm{~F}$ & 48 & Upper gingiva & Cribriform & - & Lung & + & + \\
\hline
\end{tabular}

Brachyury is a T-box transcription factor with an evolutionarily conserved function in vertebrate development, whereby it is required for mesoderm formation [13-15]. Brachyury is also highly expressed in various human epithelial tumors and human tumor cell lines (lung, colon, and prostate carcinomas), but not in human normal adult tissues [32]. However, no studies have analyzed the role of Brachyury in tumor cells. Recently, Fernando et al. [16] reported that Brachyury promotes EMT in human carcinoma cell lines. Their study demonstrated that overexpression of Brachyury in human carcinoma cells induced EMT, including upregulation of mesenchymal markers, downregulation of epithelial markers, and increase in cell migration and invasion.

Downregulation of E-cadherin transcription is induced by Brachyury overexpression and partially mediated by Slug. In our model, Brachyury was overexpressed in the ACCS-M GFP (EMT cell line), and the expression level was 2 -fold greater than that of the parental cell line. In contrast, overexpression of ZEB1 and ZEB2 in the EMT cell line was 5- and 9-fold higher, respectively, compared to parental cells. Surprisingly, Brachyury silencing by shRNA in ACCS-M GFP cells resulted in an almost complete inhibition of EMT-related genes and stem cell markers, including ZEB1 and ZEB2. This significant change induced by Brachyury silencing promoted the mesenchymal to epithelial transition (gain of E-cadherin and loss of vimentin) and loss of the CSC phenotype (sphere formation and tumorigenicity).

The mechanisms of Brachyury regulation of the EMT and stem cell-related genes are not certain. Brachyury and other members of the T-box transcription family preferentially bind to the palindromic consensus element AATTTCACACCTAGGTGTGAAATT, and a half-site (TCACACCT) of this consensus sequence is located at position -645 of the human E-cadherin promoter. Brachyury is able to bind to the E-cadherin promoter in vitro, although with low efficiency [16]. Other reports have suggested low-affinity binding of T-box proteins to a half consensus site, such as the one present in the E-cadherin promoter $[54,55]$. However, the in vivo binding of Brachyury to the half-site on the E-cadherin promoter could be greatly improved by interactions with accessory proteins or cofactors. Brachyury overexpression in tumor cells induces a concurrent enhancement of Slug expression, followed by the effective silencing of E-cadherin transcription as a result of Brachyury and Slug association within the E-cadherin promoter region [16]. 
The transcription factor Slug, but not Snail, has been shown to control desmosomal disruption during the initial and necessary steps of EMT in addition to repressing E-cadherin transcription [56,57]. Induction of EMT by FGF-1 treatment or Slug overexpression in the rat bladder carcinoma cell line NBT-II is also characterized by dissociation of desmosomes, with no change in E-cadherin expression [57]. Therefore, Slug may mainly control desmosomal proteins such as plakoglobin during the initial step of EMT and associate with Brachyury to regulate E-cadherin and accomplish EMT.

During the developmental process in vertebrates, Brachyury regulates downstream genes that are components of signaling pathways such as noncanonical Wnt/ planar cell polarity (Wnt/PCP), NFkB, and TGF- $\beta$ signaling [58]. Sox2 (SRY Sex Determining Region Y-Box2) is a member of the Sox (SRY-related HMG box) family of transcription factors. Sox2 regulates expression of multiple genes, especially stable expression of Oct-3/4, which is also a transcription factor that maintains stemness and pluripotency in normal stem cells. Recently, an association between SOX2 and EMT was also reported. Activation of SOX 2 induces TGF- $\beta$ downstream signaling including activation of Wnt, Notch, and Hedgehog signals, followed by induction of Snail mRNA expression to ultimately result in inhibition of E-cadherin transcription through induction of ZEB1/2 expression. This phenomenon is consistent with our mRNA expression results after SOX2 knockdown. Importantly, unlike Brachyury knockdown, SOX2 knockdown only inhibited genes downstream of TGF- $\beta$ and failed to inhibit Brachyury expression. In contrast, Brachyury knockdown inhibited almost all the genes tested including Sox2 and its downstream genes. Also of note, silencing of SOX2 inhibited EMT but not tumorigenicity and metastasis. Therefore, it is possible that Brachyury controls multiple functional signals related to EMT and CSC simultaneously. The impact of the simultaneous silencing effect of Brachyury on EMT and CSC phenotypes observed in this study support this hypothesis. Additionally, these data suggest the existence of a partial but direct link between the EMT and CSC and that Brachyury is one of the central regulators of EMT and CSC maintenance in AdCC cells.

The use of a single cell line is a limitation of this study. It is quite difficult to establish CSC-like cell lines in vitro and this is an obstacle to research in this field. However, parallel data from clinical samples support our hypothesis in part. Brachyury expression in clinical AdCC samples was extremely high (positive expression rate $=100 \%$ ), and the data suggested a close relationship with EMT (loss of E-cadherin and gain of vimentin). Therefore, at least the regulation mechanism of EMT by Brachyury demonstrated in this study may also occur in clinical AdCC.
From a clinical perspective, CSC-targeted therapy should have strict selectivity for CSCs, which is a serious obstacle for most molecular targeted therapies presently used. Selective expression of Brachyury has been reported in various human tumors of epithelial origin, but not in most human normal adult tissues [32], a fact that strongly encourages the use of this molecule as a clinical therapeutic target.

\section{Conclusions}

We conclude that the EMT is directly linked to CSC, and Brachyury is one of the central regulators of the EMT and CSC in our single cell line study. These results suggest that Brachyury is a potential therapeutic target for future anti-CSC treatments of AdCC.

\section{Methods}

\section{Cells and culture}

The human cell lines ACCS, ACCS GFP, and ACCS-M GFP were established in our laboratory as described previously [3]. In brief, the parental cell line ACCS and green fluorescence protein (GFP)-transfected subline ACCS-GFP displayed similar morphologies, growth rates, and tumorigenicity both in vitro and in vivo. Similar to the parental ACCS, the tumorigenicity of ACCS-GFP cells was low (22.2\% incidence). Using ACCS-GFP cells, tumor formation in the tongues of nude mice injected with tumor cells was clearly observed under excitation light, while green fluorescence was not observed in the absence of tumors. We performed in vivo selection of clones with higher tumorigenicity by repeatedly recovering cells in vitro and transplanting them into the tongues of nude mice. Consequently, a subline exhibiting high tumorigenicity (100\% incidence) and high frequency of spontaneous metastasis to submandibular lymph nodes (100\% incidence), ACCS-M GFP, was obtained through this in vivo selection process. The histological and immunohistochemical features of ACCS-M GFP tumors were similar to the solid pattern of AdCC. The cell lines were maintained as a monolayer culture in Dulbecco's modified Eagle's medium (DMEM; Sigma-Aldrich, St. Louis, MO, USA) supplemented with $10 \%$ fetal bovine serum (ICN Biomedicals, Aurora, OH, USA), 2 mML-glutamine, penicillin G, and streptomycin in a humidified incubator with an atmosphere of $5 \% \mathrm{CO}_{2}$ at $37^{\circ} \mathrm{C}$.

\section{Immunoblot analysis}

To visualize cell adhesion molecules and their related proteins, cells were rinsed with phosphate-buffered saline (PBS) and lysed in ice-cold buffer $(50 \mathrm{mM}$ Tris$\mathrm{HCl}$ [pH 7.5], $150 \mathrm{mM} \mathrm{NaCl}, 2 \mathrm{mM}$ ethylene glycol tetraacetic acid [EGTA], and 1\% Triton X-100) containing protease inhibitor cocktail (Sigma-Aldrich). The 
protein content of the lysates and fractionated samples was quantified using a protein assay kit (Bio-Rad Laboratories, Hercules, CA, USA). Equal amounts of protein from each sample were resuspended in sodium dodecyl sulfate (SDS) sample buffer (10\% SDS, $62.5 \mathrm{mM}$ Tris- $\mathrm{HCl}$ [pH 6.8], and 50\% glycerol). Before electrophoresis, reduced samples were adjusted to $5 \%(\mathrm{v} / \mathrm{v}) 2$ mercaptoethanol and boiled for $5 \mathrm{~min}$. The samples were separated on 10\% SDS-polyacrylamide gels and transferred electrophoretically onto nitrocellulose membranes (Bio-Rad Laboratories). After blocking with 5\% skim milk in Tris-buffered saline containing $0.1 \%$ Tween-20, the membranes were incubated overnight with primary antibodies at $4^{\circ} \mathrm{C}$, followed by horseradish peroxidase-conjugated secondary antibodies (DAKO, Carpinteria, CA, USA) for $1 \mathrm{~h}$. The bound antibodies were visualized using ECL immunoblotting detection reagents (Amersham Pharmacia Biotech, Piscataway, NJ, USA). The following primary antibodies were used for immunoblotting: mouse monoclonal anti-vimentin (V9) purchased from Santa Cruz Biotechnology (Santa Cruz, CA, USA); mouse monoclonal anti-E-cadherin purchased from BD Transduction Laboratories (Franklin Lakes, NJ, USA); rabbit polyclonal anti- $\beta$-catenin purchased from Upstate (Temecula, CA, USA); and mouse monoclonal anti- $\beta$-actin (A5316) purchased from Sigma-Aldrich.

\section{Real-time RT-PCR}

The mRNA expression levels of the indicated EMTrelated genes, embryonic stem cell markers (Nodal, Pax6, Rex1, Lefty, Oct-4, and Nanog), and differentiation markers (mesoderm marker, Brachyury; ectoderm marker, Sox2; endoderm marker, AFP) in ACC cells were quantified by real-time RT-PCR.

Total RNA was extracted from ACCS cells using TRIzol (Invitrogen, Carlsbad, CA, USA) and used for firststrand cDNA synthesis. The mRNA levels were quantified in triplicate using a real-time PCR system with the Brilliant SYBR Green qPCR Kit (Stratagene, La Jolla, CA, USA). The specific primers for EMT, stem cells, and differentiation markers were as follows: hSnail (F) 5'-TCCACAAGCACCAAGAGTC-3', (R) 5'-ATGGCAG TGAGAAGGATGTG-3'; hSlug (F) $5^{\prime}$-ACTGCTCCAAA ACCTTCTCC-3', (R) 5'-TGGTCAGCACAGGAGAAA ATG-3'; hTwist1 (F) 5'-CTCAGCTACGCCTTCTCG-3', (R) 5'-ACTGTCCATTTTCTCCTTCTCTG-3'; hTwist2 (F) 5'-AGGAGCTCGAGAGGCAG-3', (R) 5'-CGTTGA GCGACTGGGTG-3'; hZEB1 (F) 5'-CTCACACTCTGG GTCTTATTCTC-3', (R) 5'-GTCTTCATCCTCTTCCC TTGTC-3'; hZEB2 (F) 5'-AAAGGAGAAAGTACCAGC GG-3', (R) 5'-AGGAGTCGGAGTCTGTCATATC-3'; hT GF- $\beta$ (F) $5^{\prime}$-TTAACATCTCCAACCCAGCG-3', (R) $5^{\prime}$ TCCTGTCTTTATGGTGAAGCC-3'; hGSK3 $\beta$ (F) $5^{\prime}$ -
GGTCTATCTTAATCTGGTGCTGG-3', (R) 5'-AGGTT CTGCGGTTTAATATCCC-3'; hNodal (F) 5'-ACCCAG CTGTGTGTACTCAA-3', (R) 5'-TGGTAACGTTTCAG CAGAC-3'; hOct-4 (F) 5'-TATCGAGAACCGAGTGAGAG-3', (R) 5'-TCGTTGTGCATAGTCGCT-3'; hPax6 (F) 5'-GGCGGAGTTATGTATACCTAC-3', (R) 5'-CTT GGCCAGTATTGAGACAT-3'; hRex1 (F) 5'-AAACGG GCAAAGACAAGA-3'; (R) 5'-GCTCATAGCACACAT AGCCAT-3'; hLefty (F) 5'-TGTATCCATTGAGCCCT CT-3 $^{\prime}$, (R) 5'-CAGGAAATGGAAGGACACA-3'; hNa$\operatorname{nog}(\mathrm{F}) 5^{\prime}$-ACCCAGCTGTGTGTACTCAA-3', (R) 5'-G CGTCACCATTGCTATT-3'; hBrachyury (F) $5^{\prime}$-TGCT GCAATCCCATGACA-3', (R) 5'-CGTTGCTCACAGAC CACA-3'; hSOX2 (F) 5'-TGGGTTCGGTGGTCAAGT-3', (R) 5'-CTCTGGTAGTGCTGGGACA-3'; hAFP (F) $5^{\prime}$ CTGCAAACTGACCACGCT-3', (R) 5'-TGAGACAG CAAGCTGAGGAT-3'.

The PCR cycling conditions consisted of $10 \mathrm{~min}$ at $95^{\circ}$ $\mathrm{C}$ for 1 cycle followed by 45 cycles at $95^{\circ} \mathrm{C}$ for $30 \mathrm{~s}, 60^{\circ} \mathrm{C}$ for $30 \mathrm{~s}$, and $72^{\circ} \mathrm{C}$ for $60 \mathrm{~s}$. Dissociation curve analyses confirmed that the signals corresponded to unique amplicons. Expression levels were normalized to $\beta$-actin mRNA levels for each sample obtained from parallel assays and analyzed using the LightCycler ${ }^{\circledR} 2.0$ System software package (Roche Applied Science, Indianapolis, IN, USA).

\section{Sphere-forming assay}

ACCS cells were seeded at a density of $5 \times 10^{4}$ cells $/ \mathrm{mL}$ in $60-\mathrm{mm}$ noncoated dishes with serum-free DMEM containing $40 \mathrm{ng} / \mathrm{mL}$ basic fibroblast growth factor (bFGF) and $20 \mathrm{ng} / \mathrm{mL}$ epidermal growth factor (EGF) for floating cultures. The cells were cultured in a humidified incubator in an atmosphere of $5 \% \mathrm{CO}_{2}$ at $37^{\circ} \mathrm{C}$, and bFGF and EGF were added to the medium every other day. After 10 days, the diameters of developed cell clusters were measured, and cell clusters with a diameter $>100 \mu \mathrm{m}$ were counted as spheres. For passaging, primary spheres (day 10 ) were treated with $0.05 \%$ tryp$\sin / 0.02 \%$ EDTA and dissociated into single cells, after which the cells were added to 24-well culture plates at a density of $1 \times 10^{4}$ cells $/ \mathrm{mL}$ in serum-free medium. The cells were cultured for a further 10 days in serum-free medium to obtain secondary spheres.

\section{Transfection of Brachyury and SOX2 shRNA}

Cultured ACCS cells were transfected with shRNA lentiviral plasmids (pLKO.1-puro; Sigma-Aldrich) using Lipofectamine LTX (Invitrogen) according to the manufacturer's instructions. ACCS-sh. control and ACCS-M-sh. control cells were generated by the transfection of ACCS GFP and ACCS-M GFP cells with pLKO.1-puro Control Vector (Sigma-Aldrich), respectively. ACCS-shBra and ACCS-M-shBra cells were generated by the transfection 
of ACCS GFP and ACCS-M GFP cells with pLKO.1puro/sh. Brachyury (Sigma-Aldrich), respectively. Similarly, ACCS-shSOX2 and ACCS-M-shSOX2 cells were generated by the transfection of ACCS GFP and ACCSM GFP cells with pLKO.1-puro/sh. SOX2 (SigmaAldrich), respectively. Colonies exhibiting resistance to puromycin (Sigma-Aldrich) were pooled from the individual transfection experiments. The expression level of Brachyury in shRNA-transfected ACCS cells was monitored by real-time RT-PCR. All transfected cells were maintained in DMEM containing 10\% fetal bovine serum and $2 \mu \mathrm{g} / \mathrm{mL}$ puromycin (Sigma-Aldrich).

\section{ACCS metastatic orthotopic implantation mouse model}

The animal experimental protocols were approved by the Animal Care and Use Committee of Kyushu University. Eight-week-old female athymic nude mice (BALBcAJcl-nu) were purchased from Kyudo (Fukuoka, Japan). The mice were housed in laminar flow cabinets under specific pathogen-free conditions in facilities approved by Kyushu University. For the experimental metastasis studies, $1 \times 10^{6}$ cells in $40 \mu \mathrm{L}$ phosphatebuffered saline (PBS) were injected into the tongue using a syringe with a 27-gauge disposable needle (TOP Plastic Syringe, Tokyo, Japan) under intraperitoneal diethyl ether anesthesia. The primary tumor volumes were measured weekly, calculated as length $x$ width $\times$ thickness, and mice were sacrificed when the primary tumor volume reached $100 \mathrm{~mm}^{3}$. After sacrifice, tumors of the tongue and metastases, from tongue tumor in cervical lymph nodes, lungs, and liver were visualized macroscopically under light excitation. After visualization, the primary tumors and metastatic sites were examined pathologically and immunohistochemically.

\section{Immunohistochemistry}

All biopsies were obtained from 21 patients who had been diagnosed with primary AdCC and treated at the Department of Oral and Maxillofacial Surgery, Kyushu University Hospital, Fukuoka, Japan, between 1993 and 2006. The protocol for this research project has been approved by a suitably constituted Ethics Committee of Kyushu University. The biopsy samples were fixed in $10 \%$ neutralized buffered formalin. Consecutive 4- $\mu \mathrm{m}$ thick sections were cut, deparaffinized with xylene, and rehydrated in a graded alcohol series, followed by heat treatment with Target Retrieval Solution (Dako, Carpinteria, CA, USA), and then used for the histopathological and immunohistochemical analyses.

To block endogenous peroxide activity, $3 \% \mathrm{H}_{2} \mathrm{O}_{2}$ was applied, and nonspecific reactions were blocked with $10 \%$ normal blocking serum in Tris- $\mathrm{HCl}$ buffer. The sections were incubated overnight at $4{ }^{\circ} \mathrm{C}$ with the following primary antibodies: rabbit polyclonal anti- human Brachyury (H-210; Santa Cruz Biotechnology, Santa Cruz, CA, USA), mouse monoclonal anti-human E-cadherin (610181; BD Bioscience, California, CA, USA), and goat polyclonal anti-human vimentin (C-20; Santa Cruz Biotechnology, Santa Cruz, CA, USA). Immunostaining was performed with the Histofine SAB-PO kit (Nichirei, Tokyo, Japan), in accordance with the manufacturer's instructions. The immunolocalization of the protein was visualized using DAB substrate kit (Nichirei). The sections were counterstained with $0.5 \%$ hematoxylin, dehydrated, cleared, and mounted. Negative control staining consisted of substituting non-immune goat serum for the primary antibodies.

\section{Statistical analysis}

All data were displayed as mean $\pm \mathrm{SD}$, analyzed via analysis of variance and Student's $t$-test, and processed by the statistical software SPSS 13.0. Statistical significance was assumed at $P<0.05$

\section{Competing interests}

The authors have no potential conflicts of interest to disclose.

\section{Authors' contributions}

TS conceived of the study, participated in its design and coordination, performed experiments, analyzed data, performed statistical analysis, and drafted the manuscript. MS performed experiments, analyzed data, performed statistical analysis, and drafted the manuscript. II performed immunohistochemical staining. Kl analyzed data and helped in drafting the manuscript. SC contributed materials and helped in drafting the manuscript. YK performed experiments, analyzed data, and performed statistical analysis. KS conceived of the study and participated in its design and coordination. All authors read and approved the final manuscript.

\section{Acknowledgments}

This work was supported by Grants-in-Aid (No. 23390465) from the Ministry of Education, Culture, Sports, Science, and Technology of Japan (to T. S).

Received: 4 June 2012 Accepted: 20 August 2012

Published: 29 August 2012

\section{References}

1. Rapidis AD, Givalos N, Gakiopoulou H, Faratzis G, Stavrianos SD, Vilos GA Douzinas EE, Patsouris E: Adenoid cystic carcinoma of the head and neck. Clinicopathological analysis of 23 patients and review of the literature. Oral Oncol 2005, 41:328-335.

2. Ampil FL, Misra RP: Factors influencing survival of patients with adenoid cystic carcinoma of the salivary glands. J Oral Maxillofac Surg 1987 45:1005-1010

3. Ishii K, Shimoda M, Sugiura T, Seki K, Takahashi M, Abe M, Matsuki R, Inoue $Y$, Shirasuna K: Involvement of epithelial-mesenchymal transition in adenoid cystic carcinoma metastasis. Int J Oncol 2011, 38:921-931.

4. Tarin D, Thompson EW, Newgreen DF: The fallacy of epithelial mesenchymal transition in neoplasia. Cancer Res 2005, 65:5996-6000. discussion 6000-599.

5. Thompson EW, Newgreen DF, Tarin D: Carcinoma invasion and metastasis: a role for epithelial-mesenchymal transition? Cancer Res 2005, 65: 5991-5995. discussion 5995.

6. Grunert $\mathrm{S}$, Jechlinger $\mathrm{M}$, Beug $\mathrm{H}$ : Diverse cellular and molecular mechanisms contribute to epithelial plasticity and metastasis. Nat Rev Mol Cell Biol 2003, 4:657-665.

7. Nieto MA: The snail superfamily of zinc-finger transcription factors. Nat Rev Mol Cell Biol 2002, 3:155-166. 
8. Bolos V, Peinado H, Perez-Moreno MA, Fraga MF, Esteller M, Cano A: The transcription factor Slug represses E-cadherin expression and induces epithelial to mesenchymal transitions: a comparison with Snail and E47 repressors. J Cell Sci 2003, 116:499-511.

9. Huber MA, Kraut N, Beug H: Molecular requirements for epithelialmesenchymal transition during tumor progression. Curr Opin Cell Biol 2005, 17:548-558.

10. Yang J, Mani SA, Donaher JL, Ramaswamy S, Itzykson RA, Come C, Savagner P, Gitelman I, Richardson A, Weinberg RA: Twist, a master regulator of morphogenesis, plays an essential role in tumor metastasis. Cell 2004, 117:927-939.

11. Cano A, Perez-Moreno MA, Rodrigo I, Locascio A, Blanco MJ, del Barrio MG, Portillo F, Nieto MA: The transcription factor snail controls epithelialmesenchymal transitions by repressing E-cadherin expression. Nat Cell Biol 2000, 2:76-83.

12. Yang MH, Hsu DS, Wang HW, Wang HJ, Lan HY, Yang WH, Huang $\mathrm{CH}$, Kao SY, Tzeng CH, Tai SK, et al: Bmi1 is essential in Twist1-induced epithelialmesenchymal transition. Nat Cell Biol 2010, 12:982-992.

13. Kispert A, Herrmann BG, Leptin M, Reuter R: Homologs of the mouse Brachyury gene are involved in the specification of posterior terminal structures in Drosophila, Tribolium, and Locusta. Genes Dev 1994, 8:2137-2150.

14. Behr R, Heneweer C, Viebahn C, Denker HW, Thie M: Epithelial-mesenchymal transition in colonies of rhesus monkey embryonic stem cells: a model for processes involved in gastrulation. Stem Cells 2005, 23:805-816.

15. Vidricaire G, Jardine K, McBurney MW: Expression of the Brachyury gene during mesoderm development in differentiating embryonal carcinoma cell cultures. Development 1994, 120:115-122.

16. Fernando RI, Litzinger M, Trono P, Hamilton DH, Schlom J, Palena C: The Tbox transcription factor Brachyury promotes epithelial-mesenchymal transition in human tumor cells. J Clin Invest 2010, 120:533-544.

17. Reya T, Morrison SJ, Clarke MF, Weissman IL: Stem cells, cancer, and cancer stem cells. Nature 2001, 414:105-111.

18. Thiery JP: Epithelial-mesenchymal transitions in development and pathologies. Curr Opin Cell Biol 2003, 15:740-746.

19. Mani SA, Guo W, Liao MJ, Eaton EN, Ayyanan A, Zhou AY, Brooks M, Reinhard F, Zhang CC, Shipitsin M, et al: The epithelial-mesenchymal transition generates cells with properties of stem cells. Cell 2008, 133:704-715.

20. Berry NB, Bapat SA: Ovarian cancer plasticity and epigenomics in the acquisition of a stem-like phenotype. J Ovarian Res 2008, 1:8.

21. Ahmed N, Abubaker K, Findlay J, Quinn M: Epithelial mesenchymal transition and cancer stem cell-like phenotypes facilitate chemoresistance in recurrent ovarian cancer. Curr Cancer Drug Targets 2010, 10:268-278.

22. Blick T, Hugo H, Widodo E, Waltham M, Pinto C, Mani SA, Weinberg RA, Neve RM, Lenburg ME, Thompson EW: Epithelial mesenchymal transition traits in human breast cancer cell lines parallel the CD44(hi/)CD24 (lo/-) stem cell phenotype in human breast cancer. J Mammary Gland Biol Neoplasia 2010, 15:235-252.

23. Alison MR, Lim SM, Nicholson LJ: Cancer stem cells: problems for therapy? J Pathol 2011, 223:147-161.

24. Wang Z, Li Y, Ahmad A, Azmi AS, Kong D, Banerjee S, Sarkar FH: Targeting miRNAs involved in cancer stem cell and EMT regulation: An emerging concept in overcoming drug resistance. Drug Resist Updat 2010, 13:109-118.

25. Vazquez-Martin A, Oliveras-Ferraros C, Cufi S, Del Barco S, Martin-Castillo B, Menendez JA: Metformin regulates breast cancer stem cell ontogeny by transcriptional regulation of the epithelial-mesenchymal transition (EMT) status. Cell Cycle 2010, 9:3807-3814

26. Sarkar FH, Li Y, Wang Z, Kong D: NF-kappaB signaling pathway and its therapeutic implications in human diseases. Int Rev Immunol 2008, 27:293-319.

27. Raimondi C, Gianni W, Cortesi E, Gazzaniga P: Cancer stem cells and epithelial-mesenchymal transition: revisiting minimal residual disease. Curr Cancer Drug Targets 2010, 10:496-508.

28. Roussos ET, Keckesova Z, Haley JD, Epstein DM, Weinberg RA, Condeelis JS: AACR special conference on epithelial-mesenchymal transition and cancer progression and treatment. Cancer Res 2010, 70:7360-7364.

29. Herrmann BG, Labeit S, Poustka A, King TR, Lehrach $\mathrm{H}$ : Cloning of the $T$ gene required in mesoderm formation in the mouse. Nature 1990, 343:617-622.
30. Kispert A, Hermann BG: The Brachyury gene encodes a novel DNA binding protein. EMBO J 1993, 12:4898-4899.

31. Edwards YH, Putt W, Lekoape KM, Stott D, Fox M, Hopkinson DA, Sowden J: The human homolog $T$ of the mouse $\mathrm{T}$ (Brachyury) gene; gene structure, cDNA sequence, and assignment to chromosome 6q27. Genome Res 1996, 6:226-233

32. Palena C, Polev DE, Tsang KY, Fernando Rl, Litzinger M, Krukovskaya LL, Baranova AV, Kozlov AP, Schlom J: The human T-box mesodermal transcription factor Brachyury is a candidate target for T-cell-mediated cancer immunotherapy. Clin Cancer Res 2007, 13:2471-2478.

33. Creighton CJ, Chang JC, Rosen JM: Epithelial-mesenchymal transition (EMT) in tumor-initiating cells and its clinical implications in breast cancer. J Mammary Gland Biol Neoplasia 2010, 15:253-260.

34. Ding W, You H, Dang H, LeBlanc F, Galicia V, Lu SC, Stiles B, Rountree CB: Epithelial-to-mesenchymal transition of murine liver tumor cells promotes invasion. Hepatology 2010, 52:945-953.

35. Sarkar FH, Li Y, Wang Z, Kong D: Pancreatic cancer stem cells and EMT in drug resistance and metastasis. Minerva Chir 2009, 64:489-500

36. Monteiro J, Fodde R: Cancer stemness and metastasis: therapeutic consequences and perspectives. Eur J Cancer 2010, 46:1198-1203.

37. Singh A, Settleman J: EMT, cancer stem cells and drug resistance: an emerging axis of evil in the war on cancer. Oncogene 2010, 29:4741-4751.

38. DiMeo TA, Anderson K, Phadke P, Fan C, Perou CM, Naber S, Kuperwasser C: A novel lung metastasis signature links Wnt signaling with cancer cell self-renewal and epithelial-mesenchymal transition in basal-like breast cancer. Cancer Res 2009, 69:5364-5373.

39. Aktas B, Tewes M, Fehm T, Hauch S, Kimmig R, Kasimir-Bauer S: Stem cell and epithelial-mesenchymal transition markers are frequently overexpressed in circulating tumor cells of metastatic breast cancer patients. Breast Cancer Res 2009, 11:R46.

40. Kong D, Banerjee S, Ahmad A, Li Y, Wang Z, Sethi S, Sarkar FH: Epithelial to mesenchymal transition is mechanistically linked with stem cell signatures in prostate cancer cells. PLoS One 2010, 5:e12445.

41. Wendt MK, Allington TM, Schiemann WP: Mechanisms of the epithelialmesenchymal transition by TGF-beta. Future Oncol 2009, 5:1145-1168.

42. Kabashima A, Higuchi $H$, Takaishi $H$, Matsuzaki $Y$, Suzuki $S$, Izumiya M, lizuka H, Sakai G, Hozawa S, Azuma T, Hibi T: Side population of pancreatic cancer cells predominates in TGF-beta-mediated epithelial to mesenchymal transition and invasion. Int J Cancer 2009, 124:2771-2779.

43. Bhat-Nakshatri P, Appaiah H, Ballas C, Pick-Franke P, Goulet R Jr, Badve S, Srour EF, Nakshatri H: SLUG/SNAI2 and tumor necrosis factor generate breast cells with CD44+/CD24- phenotype. BMC Cancer 2010, 10:411.

44. Kalluri R: EMT: when epithelial cells decide to become mesenchymal-like cells. J Clin Invest 2009, 119:1417-1419.

45. Zeisberg M, Neilson EG: Biomarkers for epithelial-mesenchymal transitions. J Clin Invest 2009, 119:1429-1437.

46. Thiery JP, Sleeman JP: Complex networks orchestrate epithelialmesenchymal transitions. Nat Rev Mol Cell Biol 2006, 7:131-142.

47. Peinado $\mathrm{H}$, Olmeda D, Cano A: Snail, Zeb and bHLH factors in tumour progression: an alliance against the epithelial phenotype? Nat Rev Cancer 2007, 7:415-428.

48. Dumont N, Wilson MB, Crawford YG, Reynolds PA, Sigaroudinia M, TIsty TD: Sustained induction of epithelial to mesenchymal transition activates DNA methylation of genes silenced in basal-like breast cancers. Proc Natl Acad Sci USA 2008, 105:14867-14872.

49. Kalluri R, Weinberg RA: The basics of epithelial-mesenchymal transition. Clin Invest 2009, 119:1420-1428.

50. Acloque H, Adams MS, Fishwick K, Bronner-Fraser M, Nieto MA: Epithelialmesenchymal transitions: the importance of changing cell state in development and disease. J Clin Invest 2009, 119:1438-1449.

51. Fuxe J, Vincent T, Garcia de Herreros A: Transcriptional crosstalk between TGFbeta and stem cell pathways in tumor cell invasion: Role of EMT promoting Smad complexes. Cell Cycle 2010, 9:2363-2374.

52. Lindley LE, Briegel KJ: Molecular characterization of TGFbeta-induced epithelial-mesenchymal transition in normal finite lifespan human mammary epithelial cells. Biochem Biophys Res Commun 2010, 399:659-664.

53. Taube JH, Herschkowitz Jl, Komurov K, Zhou AY, Gupta S, Yang J, Hartwell K, Onder TT, Gupta PB, Evans KW, et al: Core epithelial-to-mesenchymal transition interactome gene-expression signature is associated with claudin-low and metaplastic breast cancer subtypes. Proc Natl Acad Sci USA 2010, 107:15449-15454. 
54. Muller CW, Herrmann BG: Crystallographic structure of the T domain-DNA complex of the Brachyury transcription factor. Nature 1997, 389:884-888.

55. Rodriguez M, Aladowicz E, Lanfrancone L, Goding CR: Tbx3 represses

E-cadherin expression and enhances melanoma invasiveness. Cancer Res 2008, 68:7872-7881.

56. Savagner P, Kusewitt DF, Carver EA, Magnino F, Choi C, Gridley T, Hudson LG: Developmental transcription factor slug is required for effective reepithelialization by adult keratinocytes. J Cell Physiol 2005, 202:858-866.

57. Savagner $P$, Yamada KM, Thiery JP: The zinc-finger protein slug causes desmosome dissociation, an initial and necessary step for growth factorinduced epithelial-mesenchymal transition. J Cell Biol 1997, 137:1403-1419.

58. Hotta K, Takahashi H, Satoh N, Gojobori T: Brachyury-downstream gene sets in a chordate, Ciona intestinalis: integrating notochord specification, morphogenesis and chordate evolution. Evol Dev 2008, 10:37-51.

doi:10.1186/1471-2407-12-377

Cite this article as: Shimoda et al.: The T-box transcription factor Brachyury regulates epithelial-mesenchymal transition in association with cancer stem-like cells in adenoid cystic carcinoma cells. BMC Cancer 2012 12:377.

\section{Submit your next manuscript to BioMed Central and take full advantage of:}

- Convenient online submission

- Thorough peer review

- No space constraints or color figure charges

- Immediate publication on acceptance

- Inclusion in PubMed, CAS, Scopus and Google Scholar

- Research which is freely available for redistribution 